\title{
Effects of a changing climate on the dynamics of coral infectious disease: a review of the evidence
}

\author{
Susanne Sokolow* \\ Department of Ecology and Evolutionary Biology, University of California Santa Cruz, 1156 High St., Santa Cruz, \\ California 95064, USA
}

\begin{abstract}
A close examination of the coral disease literature reveals many hypothesized mechanisms for how coral disease may be linked to climate change. However, evidence has been largely circumstantial, and much uncertainty remains. Here, I review the latest information on both the predicted effects of climate change in coastal marine ecosystems and current research on coral-pathogen dynamics in relation to climate variables. The published evidence supports the hypothesis that coral infectious diseases are emerging and demonstrates that coral disease research has been exponentially expanding over the last few decades. Current research suggests that environmental factors, such as ocean warming, altered rainfall, increased storm frequency, sea level rise, altered circulation, and ocean acidification may play a role in coral disease. These climate variables likely alter coral epidemiology through effects on pathogen growth rates, transmission, virulence, and susceptibility. Despite recent advances, discovering the causes of coral disease emergence at large spatial and temporal scales has been hindered by several factors including (1) the inability to rely on Koch's postulates for diseases with multifactorial etiologies, (2) the paucity of long-term, coordinated, coral disease data, and (3) the difficulty in detecting correlations in inherently non-linear, dynamic disease systems. In a rapidly changing global environment, the consequences of increasing coral disease may be severe, leading to elevated extinction risk and loss of critical reef habitat. Current evidence is still preliminary but is increasingly suggestive that mitigating the effects of climate change may help reduce the emergence of disease and improve the health of coral reef ecosystems.
\end{abstract}

KEY WORDS: Coral diseases · Emerging infectious diseases · Environmental stress · Epidemiology · Temperature $\cdot$ Marine $\cdot$ Global warming $\cdot$ Climate change $\cdot$ Causation

\section{INTRODUCTION}

There is no doubt that we live in a rapidly changing world. The average global temperature increased $0.6 \pm$ $0.2^{\circ} \mathrm{C}$ during the last century (Fig. 1) and is predicted to further increase another 1.5 to $4.5^{\circ} \mathrm{C}$ during the next, while at the same time, atmospheric $\mathrm{CO}_{2}$ concentrations have increased 100 ppm compared with preindustrial levels (Bindoff et al. 2007, Rogner et al. 2007, Rosenberg et al. 2007). The global mean sea level has been rising over the last century, with the rate of rise hastening significantly during recent decades (Bindoff et al. 2007). Ocean salinity has significantly changed over the last half century, with freshening near the poles and salinification at shallower tropical latitudes, and global oceanic $\mathrm{pH}$ has dropped approximately $0.1 \mathrm{pH}$ units since 1750 (Bindoff et al. 2007). There is wide acceptance that human activities are currently adding greenhouse gases to the atmosphere, and that these gases contribute to both warming (Crowley 2000) and chemical alteration of the oceans (Kleypas et al. 1999, Caldeira \& Wickett 2003). There is also compelling evidence that coral reefs are in precipitous decline worldwide (Hughes 1994, Hughes \& Tanner 2000, Gardner et al. 2003, Pandolfi et al. 2003). By one recent estimate, nearly one-third of reef-building corals face elevated extinction risk from climate change and other impacts (Carpenter et al. 2008). However, like many emerging fields of research, both global climate change research and coral reef science are fraught with uncer- 
(a) May-Oct

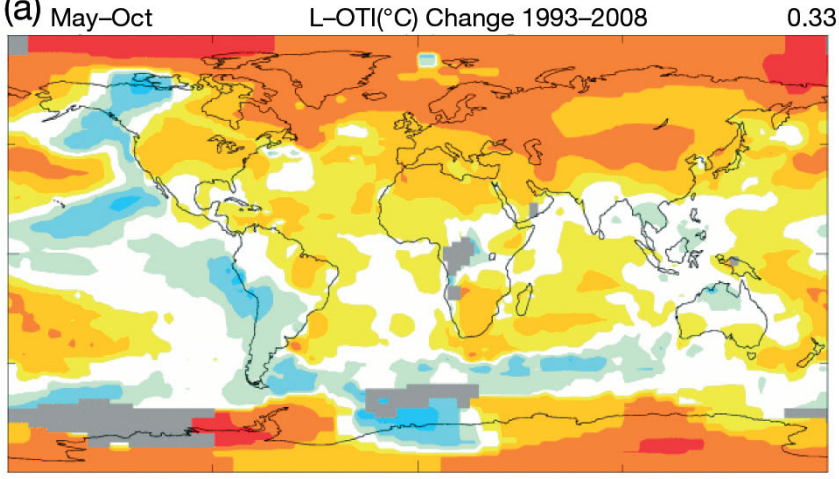

(c) May-Oct

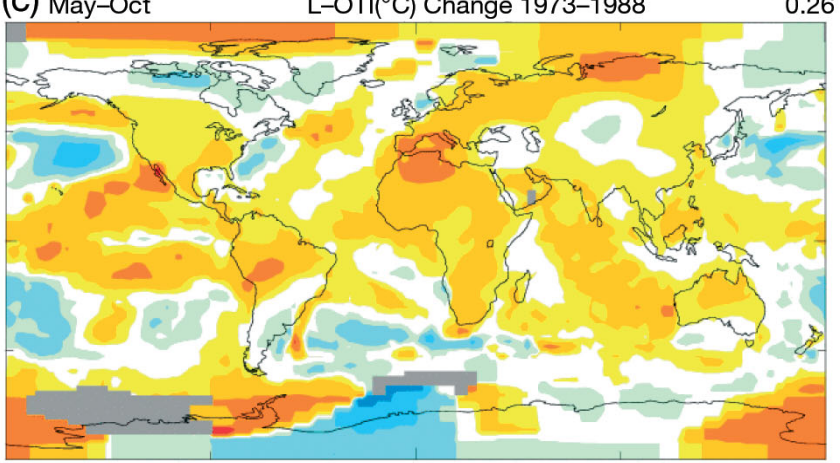

(e) May-Oct

L-OTI( $\left.{ }^{\circ} \mathrm{C}\right)$ Change $1953-1968$

$-0.03$

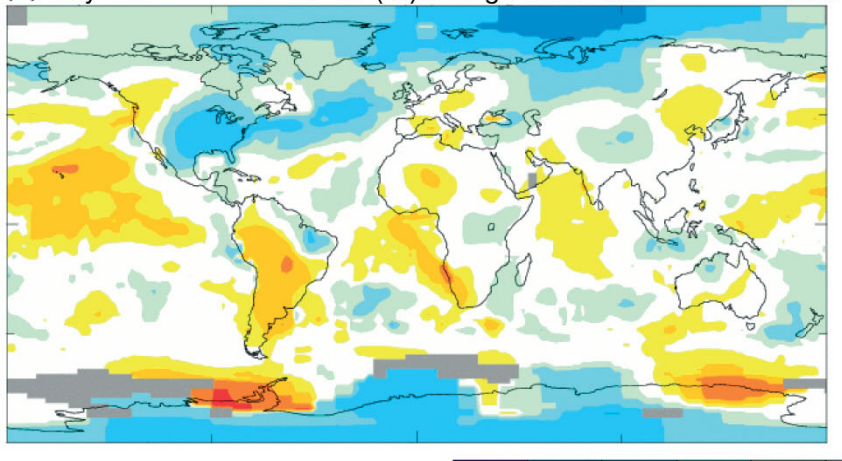

(b) Nov-Apr L-OTI $\left({ }^{\circ} \mathrm{C}\right)$ Change $1993-2008$

0.37

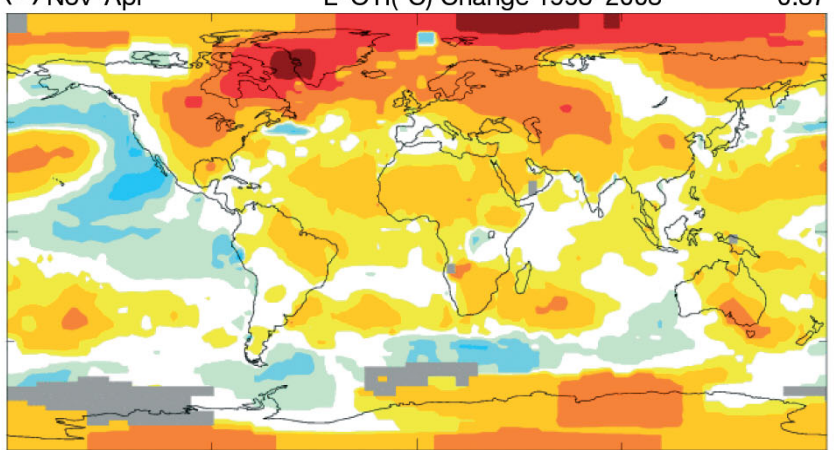

$\begin{array}{lll}\text { (d) Nov-Apr } \quad \text { L-OTI }\left({ }^{\circ} \mathrm{C}\right) \text { Change 1973-1988 } & 0.26\end{array}$

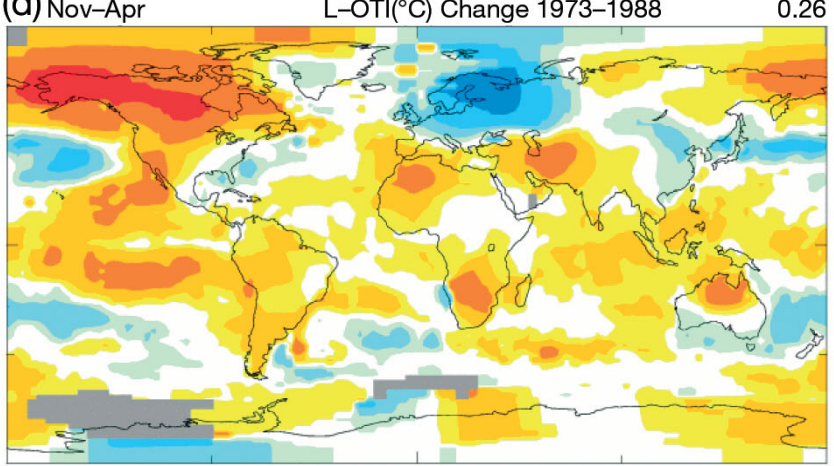

(f) Nov-Apr

L-OTI $\left({ }^{\circ} \mathrm{C}\right)$ Change $1953-1968$

$-0.05$

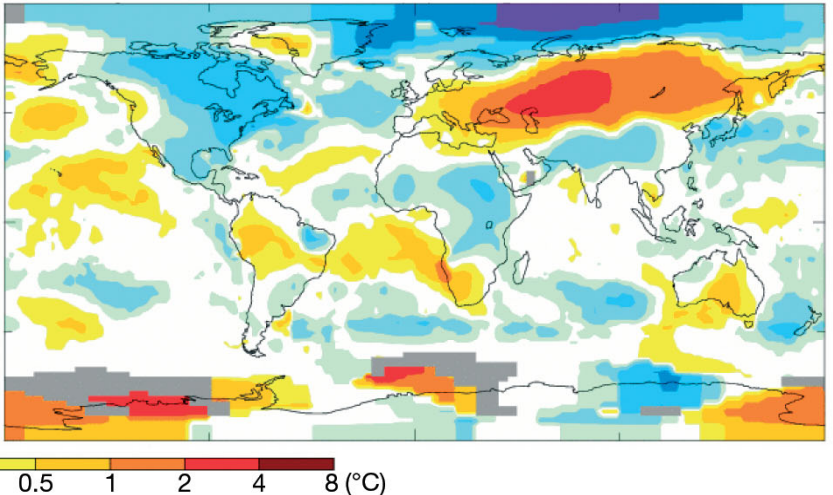

Fig. 1. Global temperature trends for the Northern Hemisphere warm (May to October averages; left side) and cold season (November to April averages; right side) for different 15 yr intervals from (a,b) 1993-2008, (c,d) 1973-1988, and (e,f) 1953-1968. Colors represent average changes over the time interval mapped. L-OTI = land-ocean temperature index. Note the accelerated warming over successive periods, with substantial global variation, and the greatest increases seen at high latitudes. Maps obtained from the NASA Goddard Institute for Space Studies (http://data.giss.nasa.gov/gistemp/maps/, accessed December 2008)

tainty, and thus, the net effects of the predicted environmental changes on the survival, health, and resilience of coral reefs are not yet fully understood (Ward et al. 2007, Maynard et al. 2008).

The most commonly cited environmental factors implicated as causes of declining coral health include: increasing ocean temperature (Harvell et al. 2002), nutrient pollution (Bruno et al. 2003), and over-fishing (Jackson et al. 2001, Hughes et al. 2003). Evidence for these factors as causative agents has been largely circumstantial (Rosenberg et al. 2007), in part because of the difficulty in trying to demonstrate causation in large and complex ecological systems (Plowright et al. 2008).

An examination of the coral disease literature reveals many hypothesized mechanisms for why increasing rates of coral disease have been reported over the last few decades, and there is much controversy. It is difficult to measure and predict the cumulative effects of global environmental change on coral health. Here, I review the hypotheses and the evidence regarding coral infectious disease emergence and potential climatic drivers. I begin by examining the evidence for the recent emergence of many coral infectious diseases. I 
then review some of the climate variables likely to change over the coming decades and how these variables may affect disease-related processes, including disease transmission, host dynamics, pathogen growth, and pathogen virulence. Finally, I discuss some current and future challenges to investigating the role of climatic factors in coral disease and decline.

\section{HOW COMMON ARE INFECTIOUS DISEASES OF CORAL TODAY, AND ARE THEY 'EMERGING?'}

'Emerging' diseases are those that have recently expanded their incidence, host range, or spatial extent (Daszak et al. 2000). A lack of underwater baseline data has hindered progress in assessing whether coral diseases are emerging. Some paleontological data suggest that the rapid loss of Acropora spp. coral in the Caribbean, beginning in the late 1970s and due in part to white band disease outbreaks, was unprecedented in the Holocene (Aronson \& Precht 2001). Data for other diseases and regions have been scarce. Ward \& Lafferty (2004) cleverly calculated a proxy measure for disease emergence in the absence of baseline data. They adjusted the number of publications related to disease within a group/taxon by the total number of reports (related to disease or not) regarding that group/taxon. Admittedly, this proxy has drawbacks because it does not explicitly control for biases resulting from increased interest or funding within subdisciplines. However, in the absence of baseline data, this proxy represents some of the only available evidence for the emergence of multiple diseases across large spatial and temporal scales. By this proxy, Ward \& Lafferty (2004) concluded that disease is significantly increasing for marine mammals, turtles, urchins, and mollusks, and significantly decreasing for fish. For coral, they concluded that the proxy measure could not detect a significant increase in diseases other than coral bleaching.

Several studies have demonstrated increasing coral diseases within sites that have been quantitatively monitored for multiple years (Porter et al. 2001, Lafferty et al. 2004, Borger \& Steiner 2005, Francini-Filho et al. 2008) and long timeseries compiled for multiple diseases in the ocean collectively suggest an increasing trend (Harvell et al. 1999). However, it has been unclear whether coral diseases, other than bleaching, are increasing beyond expectations based on increasing investigative effort.

Ward \& Lafferty's (2004) assessment reviewed articles published up until
2001. A substantial amount of additional coral disease research has amassed since their analysis. Revisiting their techniques, I compiled a list of all articles about coral disease, published up to December 2008, since the first coral disease report in 1965 (excluding those pertaining only to stress-induced bleaching). This was compared to all reports from the same time period retrieved on the ISI Web of Science (Science Citation Index Expanded v. 4.4, accessed December 2008) using the search word 'coral' (limited to subject areas that relate to ecological, oceanographic, or biological sciences, excluding human biomedical research). Both disease and non-disease reports exponentially increased over the observation period. Data were logtransformed and the slopes compared using analysis of covariance (ANCOVA), with time as a covariate. Indeed, when only records up until 2001 were included, there was no detectable increase in infectious disease reports beyond that expected by the rate of increase in all coral reports $(\mathrm{p}=0.69)$; however, including reports from the most recent $7 \mathrm{yr}$ revealed a rate of increase that was significantly greater than the background rate of increase for all coral reports (Fig. 2, $\mathrm{p}=0.01$ ). Thus, the most current available evidence suggests that coral diseases (not just bleaching) are emerging, and coral disease research is rapidly expanding.

What remains a mystery is whether these emerging diseases are predominantly infectious, whether they are manifestations of physical or physiological stress, or whether both infection and stress are involved. An infectious disease is defined as an illness caused by a transmissible biological agent, rather than by genetic, physical, or chemical agents. Transmissible agents can include viruses, bacteria, parasites, fungi, algae, and prions. Most coral diseases, other than some forms of bleaching and certain growth anomalies, are presumed to be caused by infectious pathogens, although this remains to be conclusively demonstrated for most described diseases (Richardson 1998, Lesser et al.

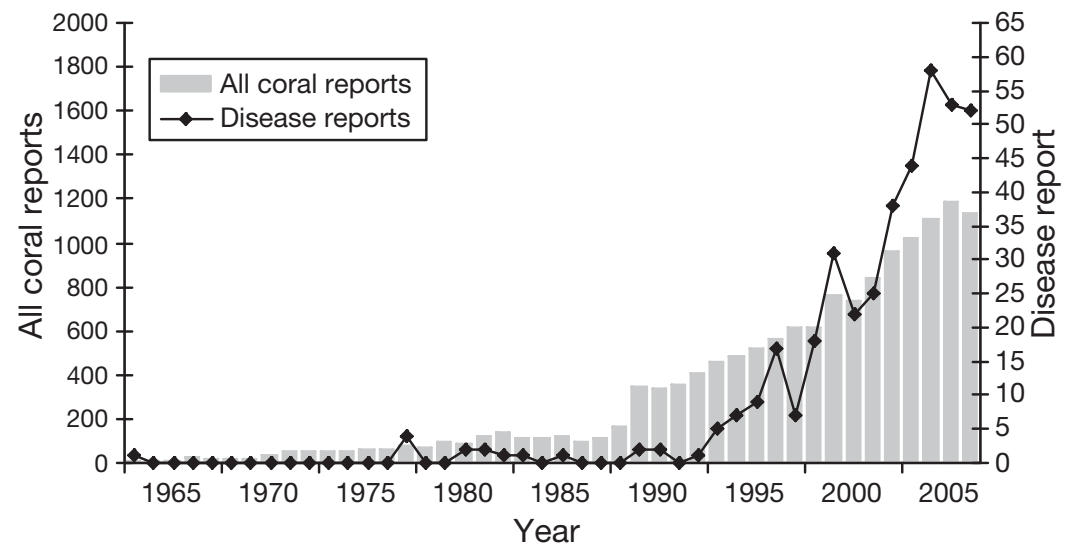

Fig. 2. Number of coral disease reports (excluding non-infectious bleaching) compared with all coral reports over time 
2007, Rosenberg et al. 2007). In a few cases, the pathogen or group of pathogens identified as causal during initial studies are no longer capable of producing disease in laboratory challenges (Rosenberg et al. 2007). Also, many coral diseases display similar signs, leading to confusion. For example, several 'white plague-like' diseases of coral have been reported in disparate regions (Croquer et al. 2003, Miller et al. 2003, Pantos et al. 2003, Dalton \& Smith 2006). Despite these obstacles, our understanding of microbial causes of coral disease is improving.

At least 6 and up to a dozen pathogens have been implicated as causes of disease in coral. This estimate varies based on different interpretations of what constitutes causation, such as different interpretations about the types of pathogens considered (e.g. whether opportunistic pathogens are included) and what types of evidence (e.g. controlled laboratory studies, field data, Koch's postulates) are sufficient for confirmation (Weil et al. 2006, Lesser et al. 2007, Rosenberg et al. 2007). The implicated pathogens, thus far, form a taxonomically diverse group including marine bacteria (Ritchie \& Smith 1995, Kushmaro et al. 1996, 1997, Ben-Haim \& Rosenberg 2002, Ben-Haim et al. 2003, Denner et al. 2003, Cervino et al. 2004, Thompson et al. 2006, Bally \& Garrabou 2007, Sussman et al. 2008), cyanobacteria and associated members of microbial consortia (Myers et al. 2007, Voss et al. 2007), bacteria from presumed terrestrial sources (Patterson et al. 2002), a ubiquitous fungus (Smith et al. 1996, Geiser et al. 1998), a protozoan (Antonius \& Lipscomb 2000), and an alga (Goldberg et al. 1984). The role of viruses as agents of coral disease remains virtually unexplored (Davy et al. 2006, Patten et al. 2008). It is not parsimonious to suppose that this diverse group of coral pathogens emerged coincidentally, although this hypothesis has not been completely ruled out. Thus, what remains in question is, why have all of these diseases emerged simultaneously?

It may be tempting to point towards anthropogenic causes of disease emergence, since coral diseases appear to have emerged concurrently over time with anthropogenic alteration of the global environment. However, a thorough review of the evidence and more basic information about disease pathogenesis will be necessary before causation can be established.

\section{CLIMATE CHANGE IN COASTAL MARINE ECOSYSTEMS}

There are numerous simultaneous manifestations of climate change that may theoretically affect coastal marine ecosystems and disease parameters, including changes in seasonality, atmospheric $\mathrm{CO}_{2}$ concentra- tions, sea surface temperature, sea level, rainfall, storm intensity, storm frequency, wave climate, and run-off (Table 1). These changes have been summarized recently by the Intergovernmental Panel on Climate Change (Bindoff et al. 2007, Nicholls et al. 2007, Trenberth et al. 2007). Precisely how these climatological changes may influence the rise and fall of coral disease outbreaks remains uncertain. Summarized in the next 4 subsections are some recently recognized climate changes and their theoretical effects on coral infectious disease (Table 1, Fig. 3), and subsequently the section 'Coral disease dynamics and climate' discusses the current evidence for environmental influences on epidemiological parameters including transmission, host population dynamics, pathogen population dynamics, and disease virulence.

\section{Seasonality and increasing sea surface temperature}

Ocean temperatures vary over space and time on seasonal, inter-annual, and decadal (or longer) time scales (Fig. 1). Many coral diseases display seasonal variation in prevalence, with higher prevalence in warm summer months (see Rosenberg et al. 2007 for examples). Strong seasonality can be taken as evidence that pathogens and/or hosts are strongly influenced by changes in seasonally fluctuating environmental variables such as temperature, but other variables such as rainfall, light levels, water clarity, run-off, ocean circulation, and nutrients can also fluctuate seasonally, along with temperature (Delcroix \& Henin 1991, Lima et al. 1996, Poulos et al. 1997). Showing that prevalence fluctuates seasonally does not conclusively demonstrate a link between temperature and coral disease.

Besides apparent seasonality, empirical evidence linking increasing ocean temperature to coral infectious disease is compelling, but not absolute. Several studies have shown temperature-regulated growth and virulence of pathogens in the laboratory (Banin et al. 2000, Alker et al. 2001, Ben-Haim et al. 2003, Remily \& Richardson 2006, Ward et al. 2007). There is some evidence that temperature-regulated bleaching events can be followed by outbreaks of infectious diseases (Guzman \& Guevara 1998, Muller et al. 2008), and some mass mortalities in coral caused by disease were coincident with periods of anomalously high water temperatures (Cerrano et al. 2000, Riegl 2002, Bruno et al. 2007). Caribbean yellow band disease prevalence around Puerto Rico, for example, was shown to significantly correlate with temperature over the past decade (Harvell et al. 2009). For some other diseases, average inter-annual changes in prevalence were not directly correlated with ocean temperature; in fact, for aspergillosis in the Florida Keys, USA, the 
Table 1. Main climate drivers for coastal marine systems, their trends due to climate change, and their possible effects on the dynamics of coral infectious diseases. $\uparrow=$ increase $; \downarrow=$ decrease; ? = uncertain; $R=$ regional variability. Adapted from the Intergovernmental Panel on Climate Change 2007 reports: Table 6.2 in Nicholls et al. (2007) and the main text in Bindoff et al. (2007) and Trenberth et al. (2007)

\begin{tabular}{|c|c|c|}
\hline Climate change & $\begin{array}{l}\text { Effects on marine and coastal } \\
\text { systems }\end{array}$ & Effects on coral infectious disease dynamics \\
\hline $\begin{array}{l}\mathrm{CO}_{2} \text { concentration } \\
(\uparrow)\end{array}$ & $\begin{array}{l}\text { Increased } \mathrm{CO}_{2} \text { fertilization; } \\
\text { decreased seawater } \mathrm{pH} \\
\text { (or 'ocean acidification') }\end{array}$ & $\begin{array}{l}\text { Slower accretion/regrowth/recovery of coral hosts } \\
\text { May increase coral stress and disease susceptibility } \\
\text { Pathogens will respond to pH change based on optimal } \\
\text { growth curves }\end{array}$ \\
\hline $\begin{array}{l}\text { Sea surface } \\
\text { temperature }(\uparrow, R)\end{array}$ & $\begin{array}{l}\text { Increased stratification/changed } \\
\text { circulation; poleward species } \\
\text { migration; increased algal blooms }\end{array}$ & $\begin{array}{l}\text { Increased host susceptibility due to temperature stress } \\
\text { Pathogens will respond to temperature based on optimal } \\
\text { growth curves }\end{array}$ \\
\hline Sea level $(\uparrow, R)$ & $\begin{array}{l}\text { Increased erosion; wetland loss } \\
\text { (and change) }\end{array}$ & $\begin{array}{l}\text { Possible increased movement of particulates, may increase } \\
\text { exposure to land-based pathogens and pollutants } \\
\text { 'Drowning' of hosts if accretion rates cannot keep up }\end{array}$ \\
\hline Storm intensity ( $\uparrow, \mathrm{R})$ & $\begin{array}{l}\text { Increased extreme water levels and } \\
\text { wave heights; increased episodic } \\
\text { erosion, storm damage }\end{array}$ & $\begin{array}{l}\text { Increased intensity of physical damage to coral hosts } \\
\text { Possible increased disease inoculation through physical } \\
\text { lesions } \\
\text { Decrease in coral abundance/density due to increased } \\
\text { storm-related mortality, especially near reef crests }\end{array}$ \\
\hline $\begin{array}{l}\text { Storm frequency }(?, \mathrm{R}) \\
\text { Storm track }(?, \mathrm{R})\end{array}$ & $\begin{array}{l}\text { Altered surges and storm waves and } \\
\text { hence risk of storm damage }\end{array}$ & $\begin{array}{l}\text { Increased frequency of physical damage to coral by storms } \\
\text { Possible increased frequency of disease inoculation through } \\
\text { physical lesions } \\
\text { Disruption of recovery and recolonization after disease events }\end{array}$ \\
\hline Wave climate $(?, \mathrm{R})$ & $\begin{array}{l}\text { Altered wave conditions, including } \\
\text { swell; altered patterns of erosion } \\
\text { and accretion }\end{array}$ & $\begin{array}{l}\text { Possible shifts in movement of particulates, may increase } \\
\text { exposure to pollutants or pathogens } \\
\text { Possible increased sediment stress }\end{array}$ \\
\hline Run-off (R) & $\begin{array}{l}\text { Altered water quality/salinity; altered } \\
\text { fluvial sediment supply; altered } \\
\text { circulation and nutrient supply }\end{array}$ & $\begin{array}{l}\text { Increased disease susceptibility from sediment stress } \\
\text { Possible increased exposure to land-based pathogens or } \\
\text { pollutants } \\
\text { Possible increased pathogen growth rates and disease } \\
\text { severity due to eutrophication }\end{array}$ \\
\hline Seasonality (R) & $\begin{array}{l}\text { Lessening of cool season temperature } \\
\text { extremes; increase in warm season } \\
\text { extremes }\end{array}$ & $\begin{array}{l}\text { Variable effects on host susceptibility and pathogen growth } \\
\text { based on optimal temperature response curves } \\
\text { Possible increase in chronic, rather than epizootic or } \\
\text { seasonal, disease }\end{array}$ \\
\hline Overland rainfall (R) & $\begin{array}{l}\text { Rainfall }(\uparrow)>30^{\circ} \text { latitude and }(\downarrow) \text { in } \\
\text { tropics; general increase in } \\
\text { droughts and 'heavy' rain events }\end{array}$ & $\begin{array}{l}\text { Possible increased exposure to land-based pathogens } \\
\text { or pollutants } \\
\text { Possible increased micronutrient supply from atmospheric } \\
\text { dust leading to faster rates of pathogen growth } \\
\text { Changes in surface salinity with probable, but unknown, } \\
\text { effects on disease }\end{array}$ \\
\hline $\begin{array}{l}\text { Ocean and air } \\
\text { circulation }(?, \mathrm{R})\end{array}$ & $\begin{array}{l}\text { Changes in El Nino Southern } \\
\text { Oscillation ( } \uparrow) \text {, North Atlantic } \\
\text { Oscillation (?), and Meridional } \\
\text { Overturning Circulation (?) }\end{array}$ & $\begin{array}{l}\text { Unknown effects on coral infectious disease } \\
\text { Possible, but unclear, changes in ocean productivity, } \\
\text { reservoirs of infection, or movements of pathogens }\end{array}$ \\
\hline
\end{tabular}

opposite relationship was seen, where disease levels steadily decreased after the outbreak peaked, even as ocean temperatures increased (Kim \& Harvell 2004). This seems confusing, since laboratory evidence shows positive associations between pathogen growth and temperature (Alker et al. 2001). The phenomenon may be explained by epidemiological dynamics such as the removal of susceptible individuals over time through death or induced disease resistance, leading to a waning of the outbreak, despite increasing temperatures. 


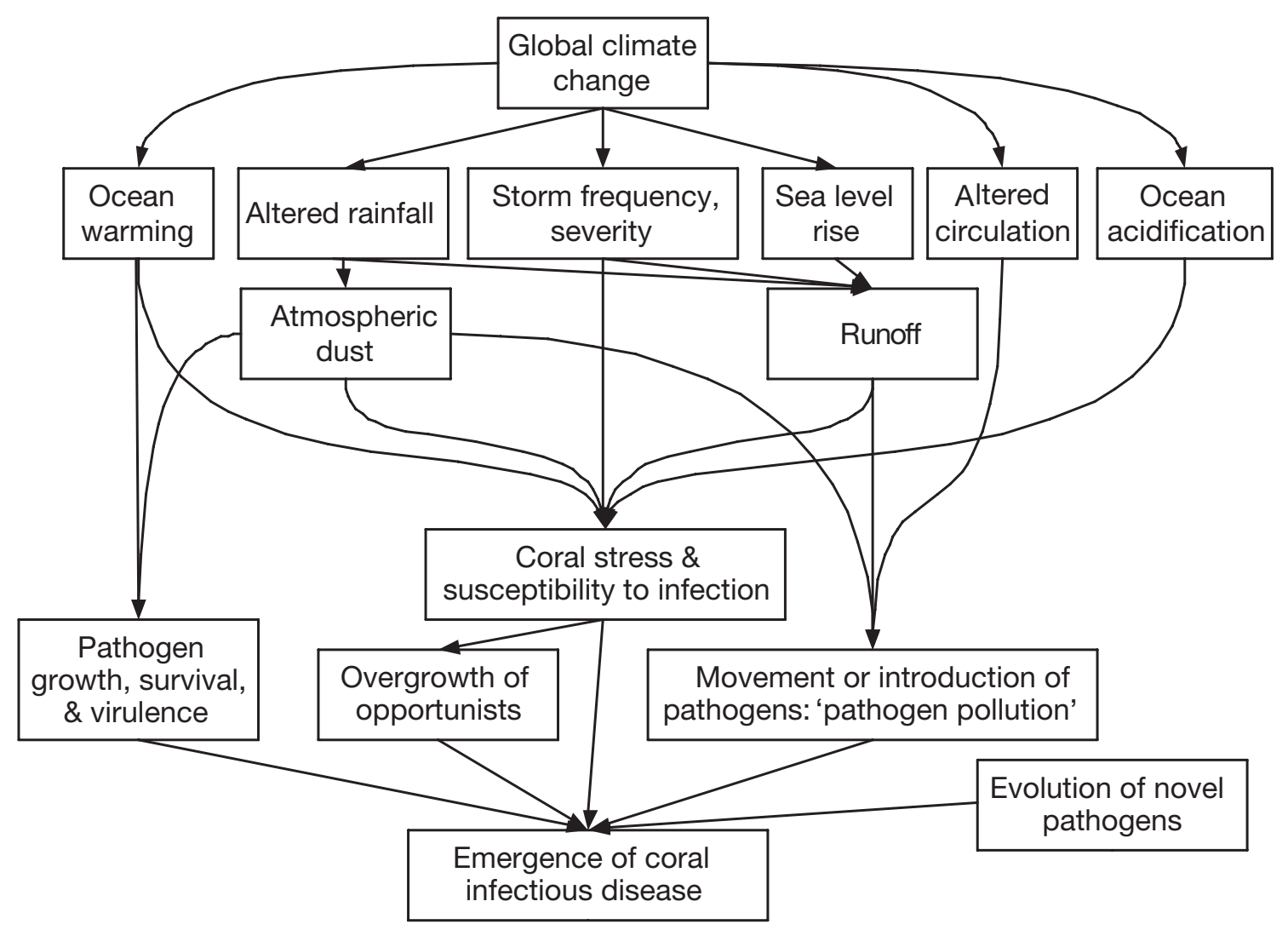

Fig. 3. Causal diagram outlining the hypothesis space for climate change as a cause of coral infectious disease emergence (not considering stress-related bleaching and other non-infectious diseases): a compilation of proposed causal pathways from the coral disease literature

For coral, there may be complex interactions between extrinsic forcing (due to temperature and environmental effects) and intrinsic dynamics (due to the interplay of epidemiological variables such as susceptibility and transmission). For aspergillosis, one laboratory study found that from 27 to $30^{\circ} \mathrm{C}$, pathogen growth increased and anti-fungal activity decreased, while at $31^{\circ} \mathrm{C}$, pathogen growth decreased and anti-fungal activity sharply increased, demonstrating the complex, non-linear relationship between temperature and epidemiological processes (Ward et al. 2007). These complications demonstrate why direct correlations between disease and temperature are not always obvious in real ecosystems, and how elucidating epidemiological dynamics, along with environmental variables, may be essential in predicting long-term disease trends.

Metapopulation models of disease have demonstrated that seasonal forcing for disease transmission (i.e. wider high and low seasonal extremes in transmission) means a higher probability of disease fade-out (or regional disease disappearance) than is predicted without seasonality (Grenfell et al. 1995). Conversely, if seasonal fluctuations in disease levels decrease as a result of less severe winters and more over-winter pathogen survival-the lessening of cold extremes has been a documented global trend accompanying global warming (Trenberth et al. 2007) - regional coral disease fade-out may become less common, and more endemic disease may occur.

If average temperatures steadily increase in the next few decades, following the recently observed trendwith 1998 to 2005 containing the top 5 warmest years on record since 1850 (Trenberth et al. 2007) - thresholds for pathogen growth and coral susceptibility may become chronically exceeded, leading to more frequent, longer outbreaks (Hughes et al. 2003). There is a limit to this effect: as temperature increases beyond the upper tolerance limits for pathogen survival, then pathogens may begin to die out during periods of maximal temperature (Lafferty et al. 2004) and outbreaks could once again become more scarce. These predictions are complicated by the likelihood that both coral hosts and pathogens will adapt over time, and current observed temperature relationships may represent 
snapshots within a shifting baseline (Done 1999, Hughes et al. 2003, Edmunds \& Gates 2008).

\section{Increased $\mathrm{CO}_{2}$ concentrations and ocean acidification}

Dissolved $\mathrm{CO}_{2}$ forms a weak acid so that the uptake of anthropogenic $\mathrm{CO}_{2}$ leads to chemical alteration of the ocean, and global mean ocean $\mathrm{pH}$ has decreased by about $0.1 \mathrm{pH}$ units since 1750 (Bindoff et al. 2007). The uptake of $\mathrm{CO}_{2}$ also shifts the balance of carbon species $\left(\mathrm{CO}_{2}\right.$-carbonate-bicarbonate) and leads to decreased ability of coral to accrete $\mathrm{CaCO}_{3}$ into their skeletons (Kleypas et al. 1999). The mean $\mathrm{pH}$ of ocean surface waters is 7.9 to 8.3 (Bindoff et al. 2007), compared to 5.8 for a typical coral surface mucous layer (Remily \& Richardson 2006). Coral pathogens have different growth rates in different $\mathrm{pH}$ conditions, and temperature can change the $\mathrm{pH}$ tolerance of pathogens (see 'Pathogen dynamics - pathogen reservoirs in the environment'). Experimental evidence and modeling predictions preceded observational evidence for changes in ocean chemistry, but acidification is now unequivocally observed in the global records (Bindoff et al. 2007). Acidification may act synergistically with other environmental stressors to increase the probability of coral species extinctions (Jackson 2008). Other than direct effects on pathogen growth and coral accretion rates, the effects of ocean acidification on coral infectious disease are relatively unknown.

\section{Storm frequency and intensity}

Globally, estimates of the frequency and potential destructiveness of hurricanes, cyclones, and typhoons show a significant upward trend: a large increase in numbers and proportion of hurricanes reaching Categories 4 and 5 has been observed since 1970, with trends strongly correlated with changes in sea surface temperature (Trenberth et al. 2007). The effects of increasing storm frequency and intensity on coral infectious disease dynamics are not completely clear. One recent study documented 'disease-like' mortality on remnant populations of Acropora palmata, a coral species federally listed as threatened, after a severe hurricane season in the Florida Keys, USA (Williams et al. 2008). Diseases that kill large branching coral, such as white band on Acropora spp., leave skeletons weakened, which can increase rates of bioerosion during storms (Riegl 2002). Increased fragmentation of weakened, diseased coral could potentially increase pathogen transmission, and stress from hurricane damage and physical lesions acquired during storms could increase coral susceptibility to infectious disease, but empirical evidence is scarce.

\section{Sea-level rise, rainfall, and increased run-off}

Sea level rose at an average rate of $1.7 \pm 0.5 \mathrm{~mm} \mathrm{yr}^{-1}$ during the 20th century, and during the period between 1993 and 2003, the rate of rise was nearly double that average (Bindoff et al. 2007). Overland rainfall has been decreasing in the tropics and increasing in temperate zones, and the frequency of drought and extreme rain events has been increasing in all areas (Trenberth et al. 2007). A combination of sealevel rise and changes in rainfall could synergistically alter run-off and salinity in coastal ecosystems.

There are multiple examples that demonstrate that increased sedimentation, nutrients, and run-off affect coral health. Experimental nutrient enrichment increases the spreading rate of several coral diseases (Bruno et al. 2003, Voss \& Richardson 2006), and nutrient limitation has been hypothesized to control microbe and algal growth in oligotrophic reef ecosystems (Szmant 2002). Lesions and tissue necrosis on Porites spp. coral were shown to positively correlate with increased wave exposure and sedimentation, although specific diseases were not distinguished (Wesseling et al. 2001). Increased sedimentation has been implicated as a driver of coral mortality through smothering and facilitating algal competition (Nugues $\&$ Roberts 2003), and spatial analyses reveal that coral reefs are currently much less likely to exist near river run-off (McLaughlin et al. 2003). Sediment damage to coral can be decreased in an experimental setting by treatment with antibiotics (Hodgson 1990), indicating a link with bacterial overgrowth. Sea level rise can result in 'drowning' of coral due to light limitations with increasing depth (Knowlton 2001), and increased runoff may elevate exposure to land-based pollutants and pathogens (Patterson et al. 2002, Lafferty et al. 2004).

\section{CORAL DISEASE DYNAMICS AND CLIMATE}

\section{Transmission rates}

Infectious coral pathogens presumably invade susceptible colonies (which become infected) and then spread to other susceptible colonies either directly through the water column or through a vector or an intermediate host. Mounting evidence has demonstrated that many, but not all, coral diseases appear to fit a contagion model of transmission (i.e. can be transferred locally from host to host), including white plague type II (Richardson et al. 1998), some growth 
anomalies (Kaczmarsky \& Richardson 2007), bacterial bleaching (Ben-Haim \& Rosenberg 2002), and black band disease (Kuta \& Richardson 1996, Bruckner et al. 1997, Page \& Willis 2006). Spatial data for other diseases, such as sea fan aspergillosis and Caribbean yellow band disease, are not consistent with contagion as the sole mode of transmission (Jolles et al. 2002, Foley et al. 2005). Evidence exists for vectored transmission of some coral diseases (Sussman et al. 2003, Nugues et al. 2004, Grober-Dunsmore et al. 2006, Miller \& Williams 2007), although vectored transmission is generally considered rare in marine compared with terrestrial systems (McCallum et al. 2004). There is no evidence of vertical transmission (spread from parent to offspring through gametes) for any described coral disease, but this may be due to a detection bias, because planulae and recruits are rarely directly studied and are not typically examined for pathogens.

Transmission rates could theoretically be affected by all the climate drivers discussed above, although empirical data are scarce, in part because transmission is difficult to measure. It was recently shown that attachment of Vibrio shiloi to coral hosts was inhibited when the bacteria were grown at low temperatures and fostered when bacteria were grown at high temperatures, indicating that transmission may be facilitated by temperature (Banin et al. 2000). Remily \& Richardson (2006) showed that increasing water temperature changed the $\mathrm{pH}$ tolerance of Aurantimonas coralicida, allowing growth to occur at acidic conditions comparable to coral mucus, suggesting that temperature may regulate $\mathrm{pH}$ tolerance and infectivity of this pathogen. Transmission is likely to be increased when hosts are stressed (Lafferty \& Holt 2003), and extreme temperature, sediment, and UV exposure can stress coral and damage zooxanthellae (Anderson et al. 2001, Sutherland et al. 2004).

\section{Host dynamics - coral recruitment and mortality rates}

Coral establishment and survival are highly dependent on available space and appropriate environmental conditions (Harrison \& Wallace 1990). Recruitment, survival, connectivity, and density of susceptible hosts are important determinants of infectious disease risk (Kermack \& McKendrick 1927, Bartlett 1957, Hess 1996, Bruno et al. 2007). Thus, stressors that affect host population dynamics may also affect infectious disease dynamics. Yet, there is very little known about the recruitment and dispersal of coral propagules, and even less is known about the effect of climate change on these processes, although coral are known to have a narrow temperature tolerance (Barber et al. 2001).
Some data support a trend of decreasing recruitment over time, coincident with collapsing coral populations, increasing temperatures, and increasing disease burdens (Connell et al. 1997). A recent study demonstrated that temperature affects larval survival in a similar manner for a wide range of marine taxa with planktonic larvae, demonstrating lower larval dispersal potential at higher temperatures, although this analysis of 72 different species of marine animals did not include any coral (O'Connor et al. 2007).

There is some evidence that coral fecundity is affected by bleaching and disease (Petes et al. 2003). For example, mean polyp fecundity has been shown to decrease with bleaching, with severely affected polyps producing as few as zero gametes for the reproductive season directly after a bleaching event (Michalek-Wagner \& Willis 2001). Larger colonies within a species are typically more fecund, and so partial mortality or changes in population size-class distributions caused by disease may decrease coral recruitment (Richardson \& Voss 2005). Conversely, dead coral skeletons exposed by infection are rarely observed hosting new coral recruits; rather, coral substrate liberated by disease mortality is usually rapidly colonized by fleshy algae (Miller et al. 2003, Borger \& Steiner 2005), although one study demonstrated no difference in recruitment to areas killed by black band disease compared with areas killed by hurricane damage (Edmunds 2000).

There is an important circular feedback predicted for coral populations affected by disease and climate change: temperature influences both host dynamics and disease, while in turn, disease influences host recruitment and mortality rates, which influences disease risk. Thus, the cumulative effects of climate change and disease on coral population dynamics over time are neither trivial to predict nor additive (Lafferty \& Holt 2003).

\section{Pathogen dynamics - pathogen reservoirs in the environment}

The relationship between environmental variables and the growth and survival of several coral pathogens have been described, including the agent of white plague type II (Remily \& Richardson 2006), the agent of sea fan aspergillosis (Alker et al. 2001, Ward et al. 2007), and several agents of bacterial bleaching (Banin et al. 2000, Ben-Haim et al. 2003). These studies report, in common, that higher temperatures lead to higher pathogen growth rates, within certain optimal growth bounds. That is, within the bounds at which most of these pathogens grow optimally, between typical tropical ocean winter $\left(15\right.$ to $\left.25^{\circ} \mathrm{C}\right)$ and summer temperatures $\left(27\right.$ to $\left.35^{\circ} \mathrm{C}\right)$, pathogen growth rates are positively 
correlated with temperature. However, for several of these pathogens, it was also demonstrated that the relationship between growth and temperature was reversed when temperatures exceeded a maximum threshold of approximately 31 to $35^{\circ} \mathrm{C}$ (Remily \& Richardson 2006, Ward et al. 2007).

\section{Disease virulence}

There is evidence that the temperature regulation of coral infectious disease can occur through temperature-sensitive induction of virulence factors, resulting in higher disease severity, transmission, or rates of disease progression. For bacterial bleaching of Oculina patagonica corals, the growth rate of the implicated pathogen Vibrio shiloi (called Vibrio strain AK1 in earlier studies) was not substantially hindered at low temperatures $\left(16^{\circ} \mathrm{C}\right)$, but virulence factors expressed by the pathogen were down-regulated (Kushmaro et al. 1998). Adhesion of the $V$. shiloi bacteria to O. patagonica hosts did not occur at either 16 or $25^{\circ} \mathrm{C}$ when the bacteria were grown at $16^{\circ} \mathrm{C}$, but did occur at both temperatures when bacteria were grown at $25^{\circ} \mathrm{C}$, suggesting that factors up-regulated in the pathogen grown at higher temperatures affected infectivity or virulence (Banin et al. 2000). Similarly, bacterial bleaching of Pocillopora damicornis corals by V. coralyticus resulted in coral tissue lysis at $27^{\circ} \mathrm{C}$, but not at lower temperatures; the pathogen was shown to express a proteinase (a virulence factor) at much higher levels when grown at $27^{\circ} \mathrm{C}$ than at lower temperatures (Rosenberg \& Ben-Haim 2002).

\section{CURRENT AND FUTURE CHALLENGES TO INVESTIGATION OF CLIMATE DRIVERS OF CORAL DISEASE}

\section{Rise and fall of coral disease outbreaks}

By nature, population-level fluctuations of infectious disease are highly dynamic: disease incidence rises as pathogens spread among susceptible hosts and then falls as infected hosts are removed by death or recovery. These systems are inherently non-linear and they pose challenges for traditional (often static) statistical analyses. More appropriate dynamic epidemiological models may assist investigation of the effects of environmental variables on disease emergence. Many insights about the dynamics of infectious disease have resulted from careful application of epidemiological models, beginning with seminal work on human diseases and terrestrial host-parasite systems nearly a century ago (e.g. Kermack \& McKendrick 1927, Bailey
1957, Bartlett 1957, Anderson \& May 1979). However, there is a clear paucity of studies applying epidemiological models to coral infectious disease, and this represents a promising research frontier both for understanding coral disease dynamics and for elucidating the connections between disease outbreaks and environmental drivers (Harvell et al. 2004). Because of the prolonged nature of coral disease outbreaks, with each outbreak lasting up to a decade (Kim \& Harvell 2004, Sokolow et al. 2009), longer-term studies are essential.

\section{Issues of scale - local management vs. global climate change}

The dynamics of coral infection (or pathogen colonization of coral) can be studied at various spatial scales, from infection of an individual polyp, to a colony, the holobiont, a local population, regional communities, and finally, the entire globe. Several coral diseases have been shown to spread widely across vast areas of reef ( $\mathrm{a}$ few $\mathrm{km}$ to hundreds of $\mathrm{km}$ ) in relatively short periods of time (weeks to months) (Richardson et al. 1998, Kim \& Harvell 2004). Because of the potential for widespread movement of disease agents, coral infection dynamics focusing at the level of individual polyps or colonies must be complemented by studies at larger spatial scales. Scales relevant to management of coral populations range from local to regional politically or geographically defined areas. Changes in climate, on the other hand, are global, although there is wide variability among regions (Fig. 1), and discovering how these global processes affect local or regional coral health is not trivial. In order to detect climate effects on coral disease, data must be collected at much larger spatial scales than currently available. This will require cooperation among investigators in disparate regions and across political boundaries.

\section{Is Koch ‘dead'?}

In 1969, at the annual conference of the Wildlife Disease Association, Dr. Robert Hanson, a distinguished virologist and then the director of the International Center for the Control of Animal Disease at the University of Wisconsin, gave a speech entitled 'Koch is dead' (reprinted in Hanson 1988) wherein he outlined the reasons why 'the ritual which has evolved [from Koch's original sound postulates] into present day experimental studies [of disease causation] has obscured almost completely what occurs in natural processes outside the laboratory' (p. 193). Hanson's speech nearly 40 yr ago has relevance for the modern problem of assessing the influence of climate change on the emergence of coral disease. 
Many diseases recognized by modern medicine have multifactorial etiologies, meaning that multiple factors are required to produce disease signs. Coral research is likewise beginning to reveal that most coral diseases probably have multifactorial etiologies. For example, Bruno et al. (2007) demonstrated that the coral disease 'white syndrome' occurred most commonly where both temperatures and coral cover were high, while Sussman et al. (2008) reproduced this disease in laboratory aquaria by introducing any 1 of 6 genetically distinct bacterial isolates. Kushmaro et al. (1997) showed that bacterial-mediated bleaching of Oculina patagonica was enhanced in warmer water and prevented when temperatures were decreased to $16^{\circ} \mathrm{C}$ or when antibiotics were applied, meaning that both appropriate temperature and bacteria were required for disease to occur.

In assessing complex diseases, it is useful to distinguish whether the many factors involved in disease causation are 'necessary', or 'sufficient', or both (Box 1). Known as the 'disease triad', specific hostpathogen-environment combinations may influence disease. Demonstrating that certain pathogens must be present does not preclude the requirement that specific environmental, physical, or host-immunologicalstatus factors must also be met for disease signs, nor vice versa. Rather, the perspective of multifactorial etiologies requires synthesis of the many drivers of coral disease emergence into a unified framework, and calls for the measurement of participation of each factor in natural ecosystems, before reaching conclusions about causation.

Koch's postulates entail 3 main criteria for establishing causality: (1) a suspected pathogen must be present in every case of the disease, (2) it should occur in no other disease as a non-pathogenic parasite, and (3) it must be isolated in pure culture, repeatedly passed, and induce the disease anew (Koch 1942). Multifactorial etiologies render Koch's postulates impossible to apply, since the postulates do not consider non-infectious factors and rely on the simplifying assumption of one-pathogen-one-disease (Wobeser 1994). Likewise, Koch's postulates are impossible to fulfill when disease is caused by non-culturable pathogens (Evans 1978); this includes many viruses and marine bacteria. For example, Israely et al. (2001) showed that 99 to $99.9 \%$ of Vibrio shiloi bacterial pathogens were in a viablebut-not-culturable state. These challenges have been recognized by many coral disease research groups, and some have offered robust biomedical research tools to overcome them (Richardson et al. 2001, Ritchie et al. 2001, Downs et al. 2005, Plowright et al. 2008, Work et al. 2008).

Although Koch's postulates can be useful, as Hansen warned in 1969, failure to fulfill the postulates does not disprove causation, nor does the reproduction of disease signs in a controlled laboratory setting demonstrate all factors capable of causing a disease. Caution

Box 1. Epidemiology of multiple causes: the concepts of necessary and sufficient. Disease signs occur only when the circles are completely shaded

In epidemiological terms, 'necessary causes' are factors that must be present for disease to occur but which alone may or may not be capable of causing disease. 'Sufficient causes' contain a complete set of factors capable of producing a disease in question. For example, in terms of coral disease, the presence of a particular microbe may be necessary but not sufficient for disease to occur (A), whereas the presence of that microbe along with an increase in water temperature may together comprise a sufficient cause of disease (B). However, if other stressors besides the increase in water temperature could produce a similar effect, then alternative stressors, such as increased sediment or ultraviolet radiation or nutrient stress, together with the presence of the microbe, may comprise another sufficient cause of the same disease (C). Similarly, if there are multiple strains or species of microbe that can fill functional groups within a pathogenic consortium, the presence of each single microbial species may not be strictly necessary to produce disease signs ( $D$ and $E$ ). The existence of these complexities highlights the importance of identifying all alternative individual factors involved in each coral disease, such as microbial pathogens or temperature, and determining causal roles as 'necessary,' 'sufficient,' or both. Experiments and field observations to assess alternative causes can clarify the significance of a single causal factor within the wider context of regional or global disease emergence.

(A) necessary but insufficient cause of disease $\mathrm{X}$

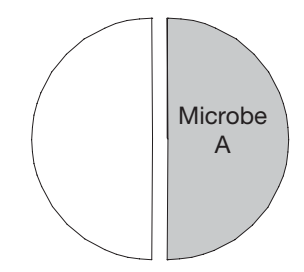

(B) sufficient cause of disease $\mathrm{X}$

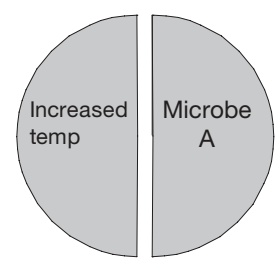

(C) alternative sufficient cause of disease $\mathrm{X}$

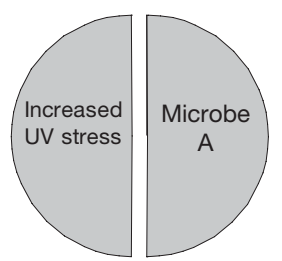

(D) sufficient cause of disease $\mathrm{X}$

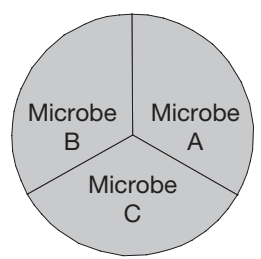

(E) alternative sufficient cause of disease $\mathrm{Y}$

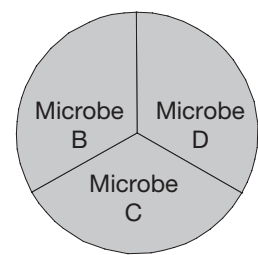


in interpreting initial challenge studies is recommended because alternative 'sufficient causes' may exist (Box 1), and factors not identified by laboratory challenge studies may nevertheless be relevant in real ecosystems.

Ultimately, a clearer understanding of all 'sufficient causes' of a disease, including all combinations of pathogens and non-infectious factors, will facilitate investigations of climatic drivers of disease emergence at the population, ecosystem, and global scales, and will guide management options. It is becoming increasingly clear that multifactorial etiologies are common among coral diseases, and that active cooperation among coral scientists and managers will be invaluable for unraveling the causal web.

\section{CONCLUSIONS}

Coral disease research has increased exponentially in the last several decades. Evidence is mounting that many coral diseases are caused by microbial pathogens and outbreaks of infectious disease are increasingly common. Researchers have recognized some of the complexities in coral disease dynamics and have expanded beyond the simple prediction that climate warming equals increased disease, but a lot of unknowns remain. Despite great strides over the last decade, much uncertainty still exists regarding the mechanisms of coral disease emergence, connections with climate variables, and the best management options. Coral reefs will inevitably continue to experience disease outbreaks, and consequently, it is feared that the synergistic effects of many compounding stressors may push coral reefs to a tipping point, propelling some species towards extinction and leading to loss of critical reef habitat (Jackson 2008). Current evidence is still preliminary but is increasingly suggestive that mitigating the effects of climate change may help reduce the emergence of disease and improve the health of coral reef ecosystems. In this rapidly changing world, discovering the environmental drivers of coral disease emergence at large spatial and temporal scales remains a challenge and a priority.

Acknowledgements. I am grateful to Elizabeth Chamberlin, John Bruno, and 2 anonymous reviewers for help with earlier drafts.

\section{LITERATURE CITED}

Alker AP, Smith GW, Kim K (2001) Characterization of Aspergillus sydowii (Thom et Church), a fungal pathogen of Caribbean sea fan corals. Hydrobiologia 460:105-111

Anderson RM, May RM (1979) Population biology of infec- tious diseases: part I. Nature 280:361-367

Anderson S, Zepp R, Machula J, Santavy D, Hansen L, Mueller E (2001) Indicators of UV exposure in corals and their relevance to global climate change and coral bleaching. Hum Ecol Risk Assess 7:1271-1282

Antonius A, Lipscomb D (2000) First protozoan coral-killer identified in the Indo-Pacific. Atoll Res Bull 481:1-21

Aronson RB, Precht WF (2001) White-band disease and the changing face of Caribbean coral reefs. Hydrobiologia 460:25-38

Bailey N (1957) The mathematical theory of epidemics. Griffin, London

Bally M, Garrabou J (2007) Thermodependent bacterial pathogens and mass mortalities in temperate benthic communities: a new case of emerging disease linked to climate change. Glob Change Biol 13:2078-2088

Banin E, Ben-Haim Y, Israely T, Loya Y, Rosenberg E (2000) Effect of the environment on the bacterial bleaching of corals. Water Air Soil Pollut 123:337-352

> Barber RT, Hilting AK, Hayes ML (2001) The changing health of coral reefs. Hum Ecol Risk Assess 7:1255-1270

Bartlett MS (1957) Measles periodicity and community size. J R Stat Soc A 120:48-70

Ben-Haim Y, Rosenberg E (2002) A novel Vibrio sp. pathogen of the coral Pocillopora damicornis. Mar Biol 141:47-55

Ben-Haim Y, Zicherman-Keren M, Rosenberg E (2003) Temperature-regulated bleaching and lysis of the coral Pocillipora damicornis by the novel pathogen Vibrio coralliilyticus. Appl Environ Microbiol 69:4236-4242

Bindoff NL, Willebrand J, Artale V, Cazenave A and others (2007) Observations: oceanic climate change and sea level. Cambridge University Press, Cambridge

Borger JL, Steiner SCC (2005) The spatial and temporal dynamics of coral diseases in Dominica, West Indies. Bull Mar Sci 77:137-154

Bruckner AW, Bruckner RJ, Williams EH (1997) Spread of a black-band disease epizootic through the coral reef system in St Ann's Bay, Jamaica. Bull Mar Sci 61:919-928

> Bruno JF, Petes LE, Harvell CD, Hettinger A (2003) Nutrient enrichment can increase the severity of coral diseases. Ecol Lett 6:1056-1061

Bruno JF, Selig ER, Casey KS, Page CA and others (2007) Thermal stress and coral cover as drivers of coral disease outbreaks. PLoS Biol 5:e124, doi:10.1371/journal.pbio. 0050124

Caldeira K, Wickett ME (2003) Anthropogenic carbon and ocean $\mathrm{pH}$. Nature 425:365

Carpenter KE, Abrar M, Aeby G, Aronson RB and others (2008) One-third of reef-building corals face elevated extinction risk from climate change and local impacts. Science 321:560-563

Cerrano C, Bavestrello G, Bianchi CN, Cattaneo-vietti R and others (2000) A catastrophic mass-mortality episode of gorgonians and other organisms in the Ligurian Sea (northwestern Mediterranean), summer 1999. Ecol Lett 3:284-293

> Cervino JM, Hayes RL, Polson SW, Polson SC, Goreau TJ, Martinez RJ, Smith GW (2004) Relationship of Vibrio species infection and elevated temperatures to yellow blotch/band disease in Caribbean corals. Appl Environ Microbiol 70:6855-6864

Connell JH, Hughes TP, Wallace CC (1997) A 30-year study of coral abundance, recruitment, and disturbance at several scales in space and time. Ecol Monogr 67:461-488

Croquer A, Pauls SM, Zubillaga AL (2003) White plague disease outbreak in a coral reef at Los Roques National Park, Venezuela. Rev Biol Trop 51:39-45 
Crowley TJ (2000) Causes of climate change over the past 1000 years. Science 289:270-277

Dalton SJ, Smith SDA (2006) Coral disease dynamics at a subtropical location, Solitary Islands Marine Park, eastern Australia. Coral Reefs 25:37-45

Daszak P, Cunningham AA, Hyatt AD (2000) Emerging infectious diseases of wildlife - threats to biodiversity and human health. Science 287:443-449

Davy SK, Burchett SG, Dale AL, Davies P and others (2006) Viruses: agents of coral disease? Dis Aquat Org 69: 101-110

$>$ Delcroix T, Henin C (1991) Seasonal and interannual variations of sea-surface salinity in the tropical Pacific Ocean. J Geophys Res Oceans 96:22135-22150

> Denner EBM, Smith GW, Busse HJ, Schumann P and others (2003) Aurantimonas coralicida gen. nov., sp. nov., the causative agent of white plague type II on Caribbean scleractinian corals. Int J Syst Evol Microbiol 53:1115-1122

Done TJ (1999) Coral community adaptability to environmental change at the scales of regions, reefs and reef zones. Am Zool 39:66-79

- Downs CA, Woodley CM, Richmond RH, Lanning LL, Owen R (2005) Shifting the paradigm of coral-reef 'health' assessment. Mar Pollut Bull 51:486-494

Edmunds PJ (2000) Recruitment of scleractinians onto the skeletons of corals killed by black band disease. Coral Reefs 19:69-74

Edmunds PJ, Gates RD (2008) Acclimatization in tropical reef corals. Mar Ecol Prog Ser 361:307-310

- Evans A (1978) Causation and disease: a chronological journey. Am J Epidemiol 108:249-258

> Foley JE, Sokolow SH, Girvetz E, Foley CW, Foley P (2005) Spatial epidemiology of Caribbean yellow band syndrome in Montastraea spp. coral in the eastern Yucatan, Mexico. Hydrobiologia 548:33-40

Francini-Filho RB, Moura RL, Thompson FL, Reis RM, Kaufman L, Kikuchi RKP, Leao ZM (2008) Diseases leading to accelerated decline of reef corals in the largest South Atlantic reef complex (Abrolhos Bank, eastern Brazil). Mar Pollut Bull 56:1008-1014

> Gardner TA, Cote IM, Gill JA, Grant A, Watkinson AR (2003) Long-term region-wide declines in Caribbean corals. Science 301:958-960

Geiser D, Taylor J, Ritchie K, Smith G (1998) Cause of sea fan death in the West Indies. Nature 394:137-138

> Goldberg WM, Makemson JC, Colley SB (1984) EntocladiaEndozoica sp. nov., a pathogenic chlorophyte: structure, life-history, physiology, and effect on its coral host. Biol Bull (Woods Hole) 166:368-383

Grenfell BT, Bolker BM, Kleczkowski A (1995) Seasonality and extinction in chaotic metapopulations. Proc R Soc Lond B Biol Sci 259:97-103

> Grober-Dunsmore R, Bonito V, Frazer TK (2006) Potential inhibitors to recovery of Acropora palmata populations in St. John, US Virgin Islands. Mar Ecol Prog Ser 321: 123-132

Guzman HM, Guevara C (1998) Massive mortality of zooxanthellate reef organisms during the 1995 bleaching in Cayos Cochinos, Honduras. Rev Biol Trop 46:165-173

Hanson RP (1988) Koch is dead (reprinted from Bulletin of the Wildlife Disease Association, Vol 5, p 150-156, 1969). J Wildl Dis 24:193-200

Harrison PL, Wallace CC (1990) Reproduction, dispersal, and recruitment of scleractinian corals. In: Dubinsky Z (ed) Ecosystems of the world, Vol 25: coral reefs. Elsevier, Amsterdam

Harvell CD, Kim K, Burkholder JM, Colwell RR and others
(1999) Emerging marine diseases - climate links and anthropogenic factors. Science 285:1505-1510

Harvell CD, Mitchell CE, Ward JR, Altizer S, Dobson AP, Ostfeld RS, Samuel MD (2002) Climate warming and disease risks for terrestrial and marine biota. Science 296: 2158-2162

> Harvell D, Aronson R, Baron N, Connell J and others (2004) The rising tide of ocean diseases: unsolved problems and research priorities. Front Ecol Environ 2:375-382

> Harvell D, Altizer S, Cattadori IM, Harrington L, Weil E (2009) Climate change and wildlife diseases: When does the host matter the most? Ecology 90:912-920

> Hess G (1996) Disease in metapopulation models: implications for conservation. Ecology 77:1617-1632

Hodgson G (1990) Tetracycline reduces sedimentation damage to corals. Mar Biol 104:493-496

Hughes TP (1994) Catastrophes, phase shifts, and large-scale degradation of a Caribbean coral reef. Science 265: $1547-1551$

Hughes TP, Tanner JE (2000) Recruitment failure, life histories, and long-term decline of Caribbean corals. Ecology 81:2250-2263

> Hughes TP, Baird AH, Bellwood DR, Card M and others (2003) Climate change, human impacts, and the resilience of coral reefs. Science 301:929-933

Israely T, Banin E, Rosenberg E (2001) Growth, differentiation and death of Vibrio shiloi in coral tissue as a function of seawater temperature. Aquat Microb Ecol 24:1-8

$>$ Jackson JBC (2008) Ecological extinction and evolution in the brave new ocean. Proc Natl Acad Sci USA 105: 11458-11465

> Jackson JBC, Kirby MX, Berger WH, Bjorndal KA and others (2001) Historical overfishing and the recent collapse of coastal ecosystems. Science 293:629-638

Jolles AE, Sullivan P, Alker AP, Harvell CD (2002) Disease transmission of aspergillosis in sea fans: inferring process from spatial pattern. Ecology 83:2373-2378

Kaczmarsky L, Richardson LL (2007) Transmission of growth anomalies between Indo-Pacific Porites corals. J Invertebr Pathol 94:218-221

Kermack W, McKendrick A (1927) Contributions to the mathematical theory of epidemics. R Stat Soc J 115:700-721

> Kim K, Harvell CD (2004) The rise and fall of a six-year coralfungal epizootic. Am Nat 164:S52-S63

> Kleypas JA, Buddemeier RW, Archer D, Gattuso JP, Langdon C, Opdyke BN (1999) Geochemical consequences of increased atmospheric carbon dioxide on coral reefs. Science 284:118-120

Knowlton N (2001) The future of coral reefs. Proc Natl Acad Sci USA 98:5419-5425

Koch R (1942) The aetiology of tuberculosis (translation of Die Aetiologie der Tuberculose [1882]). In: Clark DH (ed) Source book of medical history. Dover Publications, New York, p 392-406

Kushmaro A, Loya Y, Fine M, Rosenberg E (1996) Bacterial infection and coral bleaching. Nature 380:396

Kushmaro A, Rosenberg E, Fine M, Loya Y (1997) Bleaching of the coral Oculina patagonica by Vibrio AK-1. Mar Ecol Prog Ser 147:159-165

Kushmaro A, Rosenberg E, Fine M, Ben Haim Y, Loya Y (1998) Effect of temperature on bleaching of the coral Oculina patagonica by Vibrio AK-1. Mar Ecol Prog Ser 171:131-137

Kuta KG, Richardson LL (1996) Abundance and distribution of black band disease on coral reefs in the northern Florida Keys. Coral Reefs 15:219-223

Lafferty KD, Holt RD (2003) How should environmental stress 
affect the population dynamics of disease? Ecol Lett 6:654-664

Lafferty KD, Porter JW, Ford SE (2004) Are diseases increasing in the ocean? Annu Rev Ecol Evol Syst 35:31-54

> Lesser MP, Bythell JC, Gates RD, Johnstone RW, HoeghGuldberg O (2007) Are infectious diseases really killing corals? Alternative interpretations of the experimental and ecological data. J Exp Mar Biol Ecol 346:36-44

Lima ID, Garcia CAE, Moller OO (1996) Ocean surface processes on the southern Brazilian shelf: characterization and seasonal variability. Cont Shelf Res 16:1307-1317

> Maynard JA, Baird AH, Pratchett MS (2008) Revisiting the Cassandra syndrome; the changing climate of coral reef research. Coral Reefs 27:745-749

McCallum HI, Kuris A, Harvell CD, Lafferty KD, Smith GW, Porter J (2004) Does terrestrial epidemiology apply to marine systems? Trends Ecol Evol 19:585-591

McLaughlin CJ, Smith CA, Buddemeier RW, Bartley JD, Maxwell BA (2003) Rivers, runoff, and reefs. Global Planet Change 39:191-199

Michalek-Wagner K, Willis BL (2001) Impacts of bleaching on the soft coral Lobophytum compactum. I. Fecundity, fertilization and offspring viability. Coral Reefs 19:231-239

Miller MW, Williams DE (2007) Coral disease outbreak at Navassa, a remote Caribbean island. Coral Reefs 26: 97-101

Miller J, Rogers C, Waara R (2003) Monitoring the coral disease, plague type II, on coral reefs in St. John, US Virgin Islands. Rev Biol Trop 51:47-55

Muller EM, Rogers CS, Spitzack AS, van Woesik R (2008) Bleaching increases likelihood of disease on Acropora palmata (Lamarck) in Hawksnest Bay, St John, US Virgin Islands. Coral Reefs 27:191-195

> Myers JL, Sekar R, Richardson LL (2007) Molecular detection and ecological significance of the cyanobacterial genera Geitlerinema and Leptolyngbya in black band disease of corals. Appl Environ Microbiol 73:5173-5182

Nicholls RJ, Wang PP, Burkett VR, Codignotto JO and others (2007) Coastal systems and low-lying areas. In: Parry ML, Canziani OF, Palutikof JP, van der Linden PJ, Hanson CE (eds) Climate change 2007: impacts, adaptation and vulnerability. Contribution of Working Group II to the Fourth Assessment Report of the Intergovernmental Panel on Climate Change. Cambridge University Press, Cambridge, p 315-356

> Nugues MM, Roberts CM (2003) Coral mortality and interaction with algae in relation to sedimentation. Coral Reefs 22:507-516

Nugues MM, Smith GW, Hooidonk RJ, Seabra MI, Bak RPM (2004) Algal contact as a trigger for coral disease. Ecol Lett 7:919-923

O'Connor MI, Bruno JF, Gaines SD, Halpern BS, Lester SE, Kinlan BP, Weiss JM (2007) Temperature control of larval dispersal and the implications for marine ecology, evolution, and conservation. Proc Natl Acad Sci USA 104: 1266-1271

> Page C, Willis B (2006) Distribution, host range and largescale spatial variability in black band disease prevalence on the Great Barrier Reef, Australia. Dis Aquat Org 69:41-51

Pandolfi JM, Bradbury RH, Sala E, Hughes TP and others (2003) Global trajectories of the long-term decline of coral reef ecosystems. Science 301:955-958

Pantos O, Cooney RP, Le Tissier MDA, Barer MR, O'Donnell AG, Bythell JC (2003) The bacterial ecology of a plaguelike disease affecting the Caribbean coral Montastrea annularis. Environ Microbiol 5:370-382
Patten NL, Harrison PL, Mitchell JG (2008) Prevalence of virus-like particles within a staghorn scleractinian coral (Acropora muricata) from the Great Barrier Reef. Coral Reefs 27:569-580

> Patterson KL, Porter JW, Ritchie KE, Polson SW and others (2002) The etiology of white pox, a lethal disease of the Caribbean elkhorn coral, Acropora palmata. Proc Natl Acad Sci USA 99:8725-8730

Petes LE, Harvell CD, Peters EC, Webb MAH, Mullen KM (2003) Pathogens compromise reproduction and induce melanization in Caribbean sea fans. Mar Ecol Prog Ser 264:167-171

Plowright RK, Sokolow SH, Gorman ME, Daszak P, Foley JE (2008) Causal inference in disease ecology: investigating ecological drivers of disease emergence. Front Ecol Environ 6:420-429

Porter JW, Dustan P, Jaap WC, Patterson KL and others (2001) Patterns of spread of coral disease in the Florida Keys. Hydrobiologia 460:1-24

> Poulos SE, Drakopoulos PG, Collins MB (1997) Seasonal variability in sea surface oceanographic conditions in the Aegean Sea (Eastern Mediterranean): an overview. J Mar Syst 13:225-244

Remily ER, Richardson LL (2006) Ecological physiology of a coral pathogen and the coral reef environment. Microb Ecol 51:345-352

Richardson LL (1998) Coral diseases: What is really known? Trends Ecol Evol 13:438-443

> Richardson LL, Voss JD (2005) Changes in a coral population on reefs of the northern Florida Keys following a coral disease epizootic. Mar Ecol Prog Ser 297:147-156

> Richardson LL, Goldberg WM, Kuta KG, Aronson RB and others (1998) Florida's mystery coral-killer identified. Nature 392:557-558

Richardson LL, Smith GW, Ritchie KB, Carlton RG (2001) Integrating microbiological, microsensor, molecular, and physiologic techniques in the study of coral disease pathogenesis. Hydrobiologia 460:71-89

- Riegl B (2002) Effects of the 1996 and 1998 positive sea-surface temperature anomalies on corals, coral diseases and fish in the Arabian Gulf (Dubai, UAE). Mar Biol 140:29-40

Ritchie KB, Smith GW (1995) Preferential carbon utilization by surface bacterial communities from water mass, normal, and white-band diseased Acropora cervicornis. Mol Mar Biol Biotechnol 4:345-352

> Ritchie KB, Polson SW, Smith GW (2001) Microbial disease causation in marine invertebrates: problems, practices, and future prospects. Hydrobiologia 460:131-139

Rogner HH, Zhou D, Bradley R, Crabbe P and others (2007) Introduction. In: Metz B, Davidson OR, Bosch PR, Dave R, Meyer LA (eds) Climate change 2007: mitigation. Contribution of Working Group III to the Fourth Assessment Report of the Intergovernmental Panel on Climate Change. Cambridge University Press, Cambridge, p 96-116

> Rosenberg E, Ben-Haim Y (2002) Microbial diseases of corals and global warming. Environ Microbiol 4:318-326

Rosenberg E, Koren O, Reshef L, Efrony R, Zilber-Rosenberg I (2007) The role of microorganisms in coral health, disease and evolution. Nat Rev Microbiol 5:355-362

Smith G, Ives L, Nagelkerken I, Ritchie K (1996) Caribbean sea-fan mortalities. Nature 383:487

> Sokolow SH, Foley P, Foley JE, Hastings A, Richardson LL (2009) Disease dynamics in marine metapopulations: modelling infectious diseases on coral reefs. J Appl Ecol 46:621-631

Sussman M, Loya Y, Fine M, Rosenberg E (2003) The marine 
fireworm Hermodice carunculata is a winter reservoir and spring-summer vector for the coral-bleaching pathogen Vibrio shiloi. Environ Microbiol 5:250-255

Sussman M, Willis B, Victor S, Bourne DG (2008) Coral pathogens identified for white syndrome (WS) epizootics in the Indo-Pacific. PLoS One 3:e2393, doi:10.1371/ journal.pone.0002393

Sutherland KP, Porter JW, Torres C (2004) Disease and immunity in Caribbean and Indo-Pacific zooxanthellate corals. Mar Ecol Prog Ser 266:273-302

Szmant AM (2002) Nutrient enrichment on coral reefs: Is it a major cause of coral reef decline? Estuaries 25:743-766

Thompson FL, Barash Y, Sawabe T, Sharon G, Swings J, Rosenberg E (2006) Thalassomonas loyana sp. nov., a causative agent of the white plague-like disease of corals on the Eilat coral reef. Int J Syst Evol Microbiol 56: 365-368

Trenberth KE, Jones PD, Ambenje P, Bojariu R and others (2007) Observations: surface and atmospheric climate change. In: Solomon S, Qin D, Manning M, Chen Z and others (eds) Climate change 2007: the physical science basis. Contribution of Working Group I to the Fourth Assessment Report of the Intergovernmental Panel on Climate Change. Cambridge University Press, Cambridge, p 238-335

Voss JD, Richardson LL (2006) Nutrient enrichment enhances

Editorial responsibility: Kiho Kim, Washington, DC, USA black band disease progression in corals. Coral Reefs 25:569-576

Voss JD, Mills DK, Myers JL, Remily ER, Richardson LL (2007) Black band disease microbial community variation on corals in three regions of the wider Caribbean. Microb Ecol 54:730-739

> Ward JR, Lafferty KD (2004) The elusive baseline of marine disease: Are diseases in ocean ecosystems increasing? PLoS Biol 2:e120, doi:10.1371/journal.pbio.0020120

Ward JR, Kim K, Harvell CD (2007) Temperature affects coral disease resistance and pathogen growth. Mar Ecol Prog Ser 329:115-121

Weil E, Smith G, Gil-Agudelo DL (2006) Status and progress in coral reef disease research. Dis Aquat Org 69:1-7

Wesseling I, Uychiaoco AJ, Alino PM, Vermaat JE (2001) Partial mortality in Porites corals: variation among Philippine reefs. Int Rev Hydrobiol 86:77-85

Williams DE, Miller MW, Kramer KL (2008) Recruitment failure in Florida Keys Acropora palmata, a threatened Caribbean coral. Coral Reefs 27:697-705

Wobeser GA (1994) Investigation and management of disease in wild animals. Plenum Press, New York

- Work TM, Richardson LL, Reynolds TL, Willis BL (2008) Biomedical and veterinary science can increase our understanding of coral disease. J Exp Mar Biol Ecol 362:63-70

Submitted: January 2, 2009; Accepted: June 8, 2009

Proofs received from author(s): July 31, 2009 